\title{
Measurement of Epstein-Barr virus DNA load using a novel quantification standard containing two EBV DNA targets and SYBR Green I dye
}

\author{
Meav-Lang J Lay ${ }^{1 *}$, Robyn M Lucas², Mala Ratnamohan ${ }^{1}$, Janette Taylor ${ }^{1}$, Anne-Louise Ponsonby ${ }^{3}$,
}

Dominic E Dwyer', the Ausimmune Investigator Group (AIG)

\begin{abstract}
Background: Reactivation of Epstein-Barr virus (EBV) infection may cause serious, life-threatening complications in immunocompromised individuals. EBV DNA is often detected in EBV-associated disease states, with viral load believed to be a reflection of virus activity. Two separate real-time quantitative polymerase chain reaction (QPCR) assays using SYBR Green I dye and a single quantification standard containing two EBV genes, Epstein-Barr nuclear antigen-1 (EBNA-1) and BamHI fragment $\mathrm{H}$ rightward open reading frame-1 (BHRF-1), were developed to detect and measure absolute EBV DNA load in patients with various EBV-associated diseases. EBV DNA loads and viral capsid antigen (VCA) IgG antibody titres were also quantified on a population sample.
\end{abstract}

Results: EBV DNA was measurable in ethylenediaminetetraacetic acid (EDTA) whole blood, peripheral blood mononuclear cells (PBMCs), plasma and cerebrospinal fluid (CSF) samples. EBV DNA loads were detectable from $8.0 \times 10^{2}$ to $1.3 \times 10^{8}$ copies $/ \mathrm{ml}$ in post-transplant lymphoproliferative disease $(n=5), 1.5 \times 10^{3}$ to $2.0 \times 10^{5} \mathrm{copies} / \mathrm{ml}$ in infectious mononucleosis $(n=7), 7.5 \times 10^{4}$ to $1.1 \times 10^{5}$ copies/ml in EBV-associated haemophagocytic syndrome $(n=1)$, $2.0 \times 10^{2}$ to $5.6 \times 10^{3}$ copies $/ \mathrm{ml}$ in HIV-infected patients $(n=12)$, and $2.0 \times 10^{2}$ to $9.1 \times 10^{4} \mathrm{copies} / \mathrm{ml}$ in the population sample $(n=218)$. EBNA-1 and BHRF-1 DNA were detected in $11.0 \%$ and $21.6 \%$ of the population sample respectively. There was a modest correlation between VCA IgG antibody titre and BHRF-1 DNA load (rho $=0.13, p=0.05$ ) but not EBNA-1 DNA load (rho $=0.11, p=0.11$ ).

Conclusion: Two sensitive and specific real-time PCR assays using SYBR Green I dye and a single quantification standard containing two EBV DNA targets, were developed for the detection and measurement of EBV DNA load in a variety of clinical samples. These assays have application in the investigation of EBV-related illnesses in immunocompromised individuals.

\section{Background}

Epstein-Barr virus (EBV) causes infectious mononucleosis, an acute but self-limiting disease affecting children and young adults. After primary infection, the virus persists indefinitely in B-lymphocytes [1], only to reactivate when cellular immunity is impaired. In immunocompromised individuals, EBV-related disorders following virus reactivation are associated with significant morbidity

\footnotetext{
* Correspondence: mlay4697@uni.sydney.edu.au

'Virology Department, Centre For Infectious Diseases \& Microbiology Laboratory Services, Institute of Clinical Pathology \& Medical Research, Institute Road, Westmead Hospital, Westmead 2145, New South Wales, Australia

Full list of author information is available at the end of the article
}

and mortality [2]. Up to $15 \%$ of transplant recipients develop post-transplant lymphoproliferative disease (PTLD), a heterogeneous group of disorders characterised by EBV transformation of lymphocytes $[3,4]$. Although uncommon, PTLD is aggressive and coupled with high mortality rates of $50-80 \%$ [4]. Also related to other diseases in immunosuppressed individuals, including chronic active EBV, fatal infectious mononucleosis (IM) and EBV-associated haemophagocytic syndrome (EBVAHS) [5-7], EBV is linked to several malignancies such as nasopharyngeal carcinoma (NPC) and Burkitt's lymphoma (BL) [5]. In HIV-infected individuals, EBV is associated with diseases such as oral hairy leukoplakia and AIDS-related non-Hodgkin's lymphoma [5,8]. 
Though sometimes detectable in the immunocompetent [9], EBV DNA is found in greater concentrations in immunosuppressed populations [10-13]. The presence of circulating EBV DNA does not always correlate with symptomatic infection, nor does it predict clinical disease in immunocompetent or immunosuppressed individuals $[2,9]$. Nevertheless, although the correlation between EBV burden and disease status is incompletely understood, several studies have shown an association between symptomatic infection and elevated DNA loads in clinical samples $[14,15]$. Increasing virus burden is also believed to be a rapid indicator of immunopathological changes preceding and/or underlying the B-lymphocyte driven changes caused by EBV [16]. Therefore, determining EBV DNA loads in EBV-related disorders in immunocompromised populations is an important step towards disease diagnosis, management and treatment [17].

Several methods for quantifying absolute DNA load have been developed since its first application to EBV diagnostics in 1999 [18-20]. These include semi-quantitative, quantitative competitive and real-time PCR methods [21], with each using different means for amplicon detection; visualisation on agarose gel, Southern blot analysis and enzyme immunoassay [21]. Real-time PCR quantification is generally preferred for its wider dynamic range, speed, ease of handling, sensitivity and specificity [2,22-25]. Although commercial assays incorporating probe-based chemistries are available [26,27], in-house methods employing high saturating dyes such as SYBR Green I are more cost-effective and just as sensitive as the widely used TaqMan PCR [21,28-30].

Here, in an effort to ascertain the relationship between EBV DNA load and disease, two real-time quantitative PCR (QPCR) assays using SYBR Green I dye and a single quantification standard incorporating two separate EBV genes, Epstein-Barr nuclear antigen-1 (EBNA-1) and $\mathrm{BamHI}$ fragment $\mathrm{H}$ rightward open reading frame-1 (BHRF-1), were developed. EBV DNA was measured in a range of clinical samples, including unfractionated whole blood, plasma, PBMC and CSF from patients with EBV-associated disorders or immune dysfunctions. EBV sero-status was also determined for individuals in a population sample to assess the correlation between DNA load and antibody titres.

\section{Methods \\ Groups with EBV-associated diseases or immune disorders}

A total of 60 clinical samples from 25 individuals with various EBV-associated diseases or immune disorders were collected between February 2007 and September 2008. Specimen types included EDTA whole blood, plasma, PBMC and CSF. Each patient was assigned a letter (A to $\mathrm{Y}$ ) and classified into one of four groups.
Group 1 consisted of five patients with EBV-related PTLD following matched-unrelated donor haematopoietic stem cell transplantation, generating 40 samples: whole blood $(n=20)$, plasma $(n=18)$ and CSF $(n=2)$. Group 2 consisted of seven patients with IM, with plasma $(n=4)$ or whole blood $(n=3)$ samples and Group 3 was based on a single patient with EBVAHS from whom a whole blood sample was available. Group 4 consisted of PBMC $(n=3)$ and plasma $(n=9)$ samples from $12 \mathrm{HIV}$-infected individuals with HIV RNA plasma loads greater than 10,000 copies $/ \mathrm{ml}$.

\section{Population sample}

A fifth group was comprised of 218 individuals from a population sample for whom whole blood and serum were collected between 2004 and 2007. This included 46 males and 172 females with a mean age of 39 $(\mathrm{SD}=10)$ and $40(\mathrm{SD}=9.5)$ years respectively. These individuals resided in one of four regions in eastern Australia including Brisbane $(\mathrm{n}=78)$, Newcastle $(\mathrm{n}=28)$, Geelong and the western districts of Victoria $(\mathrm{n}=45)$ and Tasmania $(\mathrm{n}=67)$ [31].

\section{Serology testing \\ $E B V$-specific antibody detection in the population sample}

Quantitative EBV-specific serology was performed on sera from individuals in Group 5 only. EBV VCA IgG antibodies titres were determined by an immunofluorescence assay (IFA) using FITC conjugated anti-human IgG prepared in goats (Sigma-Aldrich, Castle Hill, NSW, Australia). Cells from the B95-8 marmoset cell line productively infected with EBV were grown in $27 \mathrm{mls}$ of RPMI 1640-modified (ThermoFisher Scientific, Scoresby, VIC, Australia) $+10 \%$ foetal calf serum (FCS) (ThermoFisher Scientific, Scoresby, VIC, Australia) medium containing $3 \mathrm{mls}$ of $0.4 \mathrm{mM}$ phosphonoacetic acid (Sigma-Aldrich, Castle Hill, NSW, Australia). Cells were spotted on 10 well slides (Pathech, Preston, VIC, Australia) and used as the antigen. Four-fold dilutions of known EBV positive sera were used as controls. Samples were diluted using phosphate buffered saline containing $10 \%$ FCS four-fold from 1:10 to an endpoint; samples with a titre $<1: 10$ were reported as negative, whilst titres equal to or greater than 1:10 were defined as positive.

\section{Molecular testing \\ EBV gene targets, beta-globin and PCR controls}

To maximise detection rates and reduce false negative results, two primer sets targeting the highly conserved EBV regions, EBNA-1 and BHRF-1, were used for PCR amplification (Table 1). EBNA-1 is a latent protein required for replication and genome maintenance and is the only viral protein consistently expressed in EBVinfected cells [32,33]. BHRF-1 is expressed in lytic 
Table 1 Oligonucleotides used for EBV QPCR, beta-globin detection, construction of plasmid and PCR thermal cycling conditions

\begin{tabular}{|c|c|c|c|c|c|c|}
\hline Target & $\begin{array}{l}\text { Primer } \\
\text { Name }\end{array}$ & $\begin{array}{l}\text { Oligonucleotide Sequence } \\
5^{\prime}-3^{\prime}\end{array}$ & $\begin{array}{l}\text { Amplicon } \\
\text { Length }\end{array}$ & $\begin{array}{c}\text { GenBank } \\
\text { Accession } \\
\text { (position) }\end{array}$ & Reference & $\begin{array}{l}\text { Optimised PCR Thermal } \\
\text { Cycling Conditions }\end{array}$ \\
\hline \multirow[t]{2}{*}{ EBNA-1 } & QP1 & GCC GGT GTG TTC GTA TAT GG & $213 \mathrm{bp}$ & $\begin{array}{c}\text { AJ507799 } \\
(97174-97386)\end{array}$ & $\begin{array}{l}\text { Stevens } \\
\text { et al, } 1999\end{array}$ & $\begin{array}{l}95^{\circ} \mathrm{C} \text { initial denaturation for } \\
10 \text { mins; } 58^{\circ} \mathrm{C} \text { annealing }\end{array}$ \\
\hline & QP2 & $\begin{array}{l}\text { CAA AAC CTC AGC AAA TAT } \\
\text { ATG AG }\end{array}$ & & & & \\
\hline \multirow[t]{2}{*}{ BHRF-1 } & EA-1F & GGA GAT ACT GTT AGC CCT G & $208 \mathrm{bp}$ & $\begin{array}{c}\text { AJ507799 } \\
(42105-42312)\end{array}$ & Custom & $\begin{array}{l}98^{\circ} \mathrm{C} \text { initial denaturation for } \\
13 \text { mins; } 60^{\circ} \mathrm{C} \text { annealing }\end{array}$ \\
\hline & $E A-2 R$ & $\begin{array}{l}\text { GTG TGT TAT AAA TCT GTT CCA } \\
\text { AG }\end{array}$ & & & & \\
\hline \multirow[t]{2}{*}{$\begin{array}{l}\text { Plasmid construct } \\
\text { (randomised primers in } \\
\text { bold) }\end{array}$} & EA-F & $\begin{array}{l}\text { CTA TAT GTC TGC TTA CTC } \\
\text { CGG CG /G GAG ATA CTG TTA } \\
\text { GCC CTG }\end{array}$ & $554 \mathrm{bp}$ & N/A & Custom & $\begin{array}{l}95^{\circ} \mathrm{C} \text { initial denaturation for } \\
10 \text { mins; } 55^{\circ} \mathrm{C} \text { annealing }\end{array}$ \\
\hline & EB-R & $\begin{array}{l}\text { CGC CGG AGT AAG CAG ACA } \\
\text { TAT AG /CAA AAC CTC AGC } \\
\text { AAA TAT ATG AG }\end{array}$ & & & & $\begin{array}{l}95^{\circ} \mathrm{C} \text { initial denaturation for } \\
10 \text { mins; } 55^{\circ} \mathrm{C} \text { annealing }\end{array}$ \\
\hline \multirow[t]{2}{*}{ Beta-Globin TAL57 } & $B G-1 F$ & $\begin{array}{l}\text { TAG CAA CCT CAA ACA GAC } \\
\text { ACC A }\end{array}$ & $247 \mathrm{bp}$ & $\begin{array}{r}\text { EU760960 } \\
(171-417)\end{array}$ & Custom & $\begin{array}{l}95^{\circ} \mathrm{C} \text { initial denaturation for } \\
10 \text { mins; } 61^{\circ} \mathrm{C} \text { annealing }\end{array}$ \\
\hline & $B G-1 R$ & CAG CCT AAG GGT GGG AAA AT & & & & \\
\hline
\end{tabular}

Abbreviations: EBNA-1, Epstein-Barr virus nuclear antigen-1; BHRF-1, BamHI fragment $\mathrm{H}$ rightward open reading frame-1; mins, minutes.

infection and confers anti-apoptotic properties similar to Bcl-2 for enhancing cell survival [34]. Groups 2-5 were evaluated by both PCR targets, while inadequate sample volume limited testing to EBNA-1 in Group 1. The beta-globin gene targeting the TAL57 region was used as a 'house-keeping' gene to control for PCR inhibitors and check for DNA integrity [35]. All samples were subjected to beta-globin PCR prior to EBV QPCR. Contamination was monitored by the use of PCR-grade water and no template DNA controls.

\section{DNA extraction and molecular assay design}

DNA was isolated from $200 \mu \mathrm{l}$ of EDTA whole blood, plasma or CSF using the GenElute ${ }^{\text {Tux }}$ Mammalian Genomic DNA Miniprep $\mathrm{Kit}^{\oplus}$ (Sigma-Aldrich, Caste Hill, NSW Australia) according to the manufacturer's instructions, and eluted in $200 \mu$ l elution buffer. The QIAamp DNA mini kit (Qiagen, Doncaster, VIC, Australia) was used to extract DNA from PBMC in accordance with the manufacturer's instructions. Extracts were aliquoted in single use volumes to prevent freeze-thaw cycles and stored at $-80^{\circ} \mathrm{C}$ prior to testing. Each reaction mixture was contained in a PCR-certified colourless $200 \mu \mathrm{l}$ flat capped tube (Integrated Sciences, Willoughby, NSW, Australia) to a final $25 \mu \mathrm{l}$ volume, comprising of $2.0 \mu \mathrm{l}$ LightCycler ${ }^{\oplus}$ FastStart DNA Master SYBR Green 1 dye (Roche Diagnostics, Castle Hill, NSW, Australia) at $10 \times$ concentration precombined with the LightCycler ${ }^{\circ}$ FastStart enzyme, $0.5 \mu \mathrm{l}$ of $0.2 \mathrm{mM}$ sense and antisense primers (Invitrogen, Mount Waverley, VIC, Australia), $0.8 \mu \mathrm{l}$ of $25 \mathrm{mM} \mathrm{MgCl}_{2}$ and $5 \mu \mathrm{l}$ of the DNA eluate. Samples were tested on the 36-well rotor on the Rotor-Gene $6000^{\circ}$ analyser (Qiagen, Doncaster, VIC, Australia). PCR was divided into two cycles: a first cycle with three repeats at 40 seconds for each stage, and a second cycle with 40 repeats at 30 seconds per stage. Thermal cycling conditions included an optimised initial denaturation step followed by $95^{\circ} \mathrm{C}$ denaturation, optimised annealing temperatures and extension at $72^{\circ} \mathrm{C}$ (Table 1). To ensure complete product formation, a final extension step at $72^{\circ} \mathrm{C}$ for 5 minutes concluded the PCR. A melt analysis immediately followed at between $60^{\circ} \mathrm{C}$ to $99^{\circ} \mathrm{C}$ as a check for amplicon purity. For confirmation, EBNA-1 and BHRF-1 products were electrophoresed in 2\% agarose gel containing 1:20 dilution of SYBR ${ }^{\circ}$ safe DNA gel stain in $0.5 \times$ TBE buffer (Invitrogen, Mount Waverley, VIC, Australia).

\section{Cloning of EBNA-1 and BHRF-1 DNA targets into plasmid} vector $P G E M$ and standard curve construction

A novel feature of the assay was the design of a quantification standard incorporating both EBNA-1 and BHRF-1 DNA targets in a single plasmid (Figure 1). This was done to minimise the necessity for two separate EBV standards, thus reducing costs and labour. The EBNA- 1 and BHRF-1 DNA targets were linked using randomised primers (Table 1) and inserted into the pGEM vector, using the pGEM $^{\circ}$-T Easy Vector System II (Promega Corporation, Alexandria, NSW, Australia) according to the manufacturer's instructions. The cloned targets were then purified using the PureYield ${ }^{\text {tu }}$ Plasmid MidiPrep System (Promega Corporation, Alexandria, NSW, Australia), and stored in single use aliquots. Target copy number was calculated following double stranded DNA approximation using the Beckman DU 530 Life Science UV/Vis spectrophotometer (Beckman Coulter, Gladesville, NSW, Australia). A new plasmid aliquot was used for standard curve dilution for 


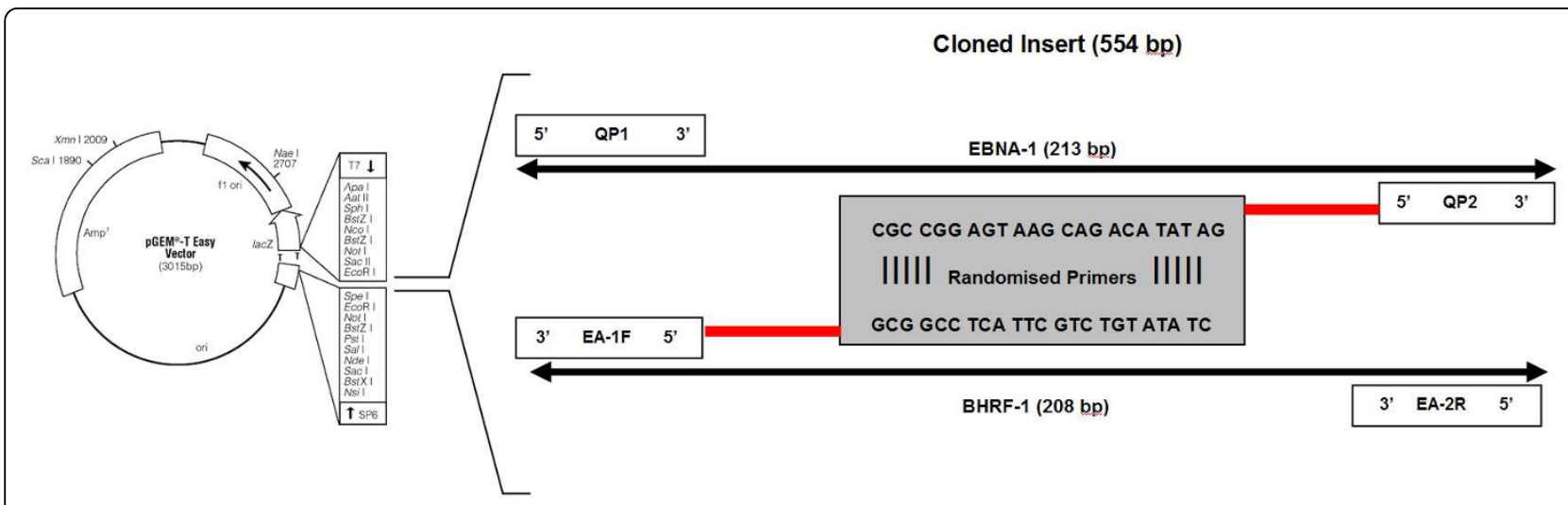

Figure 1 Plasmid vector PGEM showing location of cloned insert.

each PCR run consisting of three replicates starting at $10^{1}$ to $10^{6}$ copies $/ 5 \mu \mathrm{l}$. PCR runs were accepted when the standard curve correlation co-efficient was $\geq 0.99$.

Product identification, reproducibility, sensitivity, limit of detection and specificity

PCR products were identified by an amplification curve, melt analyses and amplification efficiency generated by the Rotor-Gene $^{\text {Tat }} 6000$ Software 1.7 (Build 90). Positive EBV DNA samples had a cycle threshold (CT) less than 40 , and melted between $86^{\circ} \mathrm{C}$ to $87^{\circ} \mathrm{C}$ with an average amplification efficiency of 1.74. PCR products for EBNA-1 DNA and BHRF-1 DNA were identified on agarose gel by 213 bp and 208 bp bands, respectively. Reproducibility studies consisting of triplicates of each standard curve dilution $\left(10^{1}-10^{5}\right.$ copies $\left./ 5 \mu \mathrm{l}\right)$ were performed prior to testing. Intra-assay variation was determined in three repeat assays tested within 24 hours on three consecutive days. Interassay variation was assessed using three different batches of the same PCR master mix kit. Sensitivity was determined by end-point PCR using gel electrophoresis. To establish the minimum DNA copy number that could be reliably detected, ten plasmid replicates spanning $10^{\circ}$ to $10^{2}$ copies/ $5 \mu$ were assayed in three separate runs. Primer specificity was verified on the Basic Local Alignment Search Tool on GenBank and by assaying known cytomegalovirus (CMV), human herpesvirus 6 (HHV6), HIV and varicella zoster (VZV) positive samples. The EBV QPCR was evaluated against an external quality assurance program (Quality Control for Medical Diagnostics (QCMD), Glasgow, Scotland, http://www.qcmd.org/ for EBV QPCR in 2008 and 2009.

\section{Viral load calculation and result interpretation}

Viral load calculations were based on DNA extraction volume and final elution volumes as well as the number of replicates tested. Samples were extracted and eluted in equal quantities, keeping ratios constant. Hence, the amount of sample used for PCR $(5 \mu \mathrm{l})$ was multiplied by a factor of 200 (elution volume) and divided by the number of replicates to obtain a final measurement expressed as DNA copies per millilitre (copies/ml) of sample. This unit of measurement has close correlations with copies per microgram of DNA, therefore does not require normalisation to the amount of input DNA [36]. Furthermore, copies $/ \mathrm{ml}$ removes unnecessary processing steps and reduces costs, as well as minimising sample volume for testing. EBV DNA was quantifiable in a dynamic range spanning six logarithms with the minimum reportable viral load at $2.0 \times 10^{2}$ copies $/ \mathrm{ml}$ of sample. Samples with no detectable target DNA were assigned a load of zero and resulted as negative.

\section{Statistical calculations}

Data analysis was conducted with SPSS version 17. Spearman's (rho) correlation co-efficient was used to assess the correlations between EBNA-1 and BHRF-1 DNA loads and VCA IgG antibody titres.

\section{Results}

Performance of EBV QPCR assays: reproducibility, sensitivity, detection limit and specificity

The intra-assay and inter-assay co-efficient of variation for EBNA-1 and BHRF-1 QPCRs are shown in Table 2. Both EBV targets were detected at levels as low as $2.0 \times$ $10^{2}$ copies $/ \mathrm{ml}$ of sample. However, the reliable limit of detection for both EBNA-1 and BHRF-1 DNA was $2.0 \times$ $10^{3}$ copies $/ \mathrm{ml}$, where the proportion that were detected (positivity ratio) were $97 \%$ and $93 \%$ respectively. Primers showed no cross reactivity to other herpesviruses (data not shown). All samples in both the 2008 and 2009 QCMD programs were correctly identified using the EBNA-1 primers.

\section{EBV detection and load in EBV-associated disease states and immunocompromised individuals}

Of the 60 samples from 25 immunocompromised patients, $30(50 \%)$ samples from $16(64 \%)$ patients had 
Table 2 Intra- and inter-assay co-efficient of variation for EBNA-1 and BHRF-1 QPCRs

\begin{tabular}{|c|c|c|c|c|c|c|}
\hline $\begin{array}{l}\text { DNA Target } \\
\text { (copies/5 ul) }\end{array}$ & Mean CT & $\begin{array}{l}\text { Mean R-G } 6000^{\mathrm{Tm}} \text { Results } \\
\text { (copies/5ul) }\end{array}$ & $\begin{array}{c}\text { Standard Deviation of R-G } 6000^{\mathrm{Tm}} \text { Results } \\
\text { (copies/5ul) }\end{array}$ & Mean \% Variation & $\begin{array}{l}\mathrm{COV} \\
(\%)\end{array}$ & Mean $\mathrm{R}^{2}$ \\
\hline \multicolumn{7}{|c|}{ EBNA-1 Intra-Assay Variation (same day) } \\
\hline 100,000 & 18.03 & 87,329 & 6,670 & $12.68 \%$ & 7.64 & 0.991 \\
\hline 10,000 & 21.28 & 11,735 & 3,092 & $26.30 \%$ & 26.34 & \\
\hline 1,000 & 25.21 & 1,057 & 100 & $7.00 \%$ & 9.50 & \\
\hline 100 & 29.10 & 103 & 38 & $32.12 \%$ & 37.25 & \\
\hline 10 & 32.91 & 11 & 6 & $46.16 \%$ & 57.50 & \\
\hline \multicolumn{7}{|c|}{ EBNA-1 Intra-Assay Variation (different days) } \\
\hline 100,000 & 16.94 & 89,643 & 8,164 & $11.00 \%$ & 9.11 & 0.998 \\
\hline 10,000 & 20.31 & 10,678 & 1,207 & $10.00 \%$ & 11.31 & \\
\hline 1,000 & 23.85 & 1,133 & 129 & $16.00 \%$ & 11.41 & \\
\hline 100 & 27.65 & 102 & 4 & $3.00 \%$ & 3.90 & \\
\hline 10 & 31.42 & 10 & 2 & $17.88 \%$ & 18.95 & \\
\hline \multicolumn{7}{|c|}{ BHRF-1 Intra-Assay Variation (same day) } \\
\hline 100,000 & 17.23 & 97,884 & 9,144 & $8.08 \%$ & 9.34 & 0.994 \\
\hline 10,000 & 20.91 & 9,852 & 542 & $4.45 \%$ & 5.50 & \\
\hline 1,000 & 24.38 & 1,146 & 202 & $16.12 \%$ & 17.64 & \\
\hline 100 & 28.43 & 94 & 19 & $17.70 \%$ & 20.51 & \\
\hline 10 & 31.95 & 11 & 5 & $35.38 \%$ & 41.91 & \\
\hline \multicolumn{7}{|c|}{ BHRF-1 Intra-Assay Variation (different days) } \\
\hline 100,000 & 18.05 & 105,387 & 4,621 & $6.02 \%$ & 4.38 & 0.997 \\
\hline 10,000 & 21.75 & 9,779 & 818 & $6.23 \%$ & 8.37 & \\
\hline 1,000 & 25.23 & 1,042 & 141 & $11.63 \%$ & 13.55 & \\
\hline 100 & 29.06 & 89 & 18 & $13.76 \%$ & 19.88 & \\
\hline 10 & 32.66 & 12 & 2 & 25.30 & 16.53 & \\
\hline \multicolumn{7}{|c|}{ EBNA-1 Inter-Assay Variation } \\
\hline 100,000 & 19.87 & 101,644 & 14,058 & $10.99 \%$ & 28.35 & 0.990 \\
\hline 10,000 & 23.75 & 10,660 & 1,471 & $13.65 \%$ & 13.80 & \\
\hline 1,000 & 27.68 & 1,084 & 191 & $18.67 \%$ & 17.60 & \\
\hline 100 & 31.71 & 111 & 49 & $33.58 \%$ & 43.75 & \\
\hline 10 & 35.86 & 12 & 9 & $65.03 \%$ & 75.85 & \\
\hline \multicolumn{7}{|c|}{ BHRF-1 Inter-Assay Variation } \\
\hline 100,000 & 17.30 & 109,065 & 14,266 & $10.01 \%$ & 13.08 & 0.990 \\
\hline 10,000 & 21.49 & 9,209 & 2,154 & $16.84 \%$ & 23.39 & \\
\hline 1,000 & 25.49 & 860 & 251 & $22.19 \%$ & 29.15 & \\
\hline 100 & 29.01 & 108 & 49 & $35.53 \%$ & 45.33 & \\
\hline 10 & 32.29 & 15 & 8 & $69.41 \%$ & 57.23 & \\
\hline
\end{tabular}

Abbreviations: CT, cycle threshold; Mean \% variation, average percentage variation between the calculated (Rotor-Gene results) and the given concentration (DNA target); COV, co-efficient of variation is the ratio of standard deviation to the mean; $\mathrm{R}^{2}$-value, square root of the correlation co-efficient - in quantitation PCR describes the percentage of the data which matches the hypothesis that the standards conform to a line of best fit.

quantifiable viral load using one or other of the EBV DNA targets, EBNA-1 or BHRF-1 (Table 3). EBV DNA was detected in $100 \%, 85.7 \%, 100 \%$ and $33.3 \%$ of patients with PTLD, IM, EBVAHS and HIV-infected individuals (Groups 1 to 4), respectively. EBV DNA loads were detectable at ranges from $2.0 \times 10^{2}$ to $1.3 \times$ $10^{8}$ copies $/ \mathrm{ml}$ in these clinical samples, with the highest EBV DNA load recorded in an individual with PTLD $\left(1.3 \times 10^{8}\right.$ copies $/ \mathrm{ml}$ of sample $)$. High levels were also seen in individuals with IM $\left(2.0 \times 10^{5}\right.$ copies $/ \mathrm{ml}$ of sample), EBVAHS $\left(1.1 \times 10^{5}\right.$ copies $/ \mathrm{ml}$ whole blood $)$, and HIV infection $\left(5.6 \times 10^{3}\right.$ copies $/ \mathrm{ml}$ of sample).

In Group 1 (PTLD), EBV DNA concentrations spanned six logarithms and were detected in multiple samples from early to end-stage disease. EBV DNA loads increased sequentially following transplantation, decreased after anti-viral therapy in Patients $\mathrm{A}$ and $\mathrm{C}$ and peaked ten days prior to death in Patients A to D. EBV DNA loads were detectable in some samples, but were absent in others. In Patient D, plasma EBV DNA was qualitative PCR negative 
Table 3 EBV DNA loads in various EBV-associated disease states and immunocompromised individuals

\begin{tabular}{|c|c|c|c|c|c|c|c|}
\hline Group & $\begin{array}{l}\text { Patient } \\
\text { ID }\end{array}$ & Sex/Age & Condition & $\begin{array}{l}\text { Specimen } \\
\text { (Positive/n Tested) }\end{array}$ & Target & $\begin{array}{l}\text { Detectable EBV DNA } \\
\text { Load (copies/ml) }\end{array}$ & Clinical Notes \\
\hline \multirow[t]{19}{*}{1.} & A. & $M / 46 y$ & PTLD & Plasma $(5 / 6)$ & EBNA-1 & Day $+32-8.0 \times 10^{2}$ & $\begin{array}{l}\text { MUD HSCT for AML; EBV VCA IgG positive } \\
\text { pre-Tx; Plasma collected on Days }+32,+39, \\
+46,+60,+75 \text { and }+81 \text { for EBV QPCR; Plasma } \\
\text { EBV (qualitative) PCR positive on Days }+75 \text {, } \\
+78 \text { and }+81 \text {; Treatment with Foscarnet and } \\
\text { Rituximab after Day }+75 \text {; Died of pneumonia } \\
\text { on Day }+88\end{array}$ \\
\hline & & & & & & Day $+46-1.0 \times 10^{3}$ & \\
\hline & & & & & & Day $+60-8.8 \times 10^{3}$ & \\
\hline & & & & & & Day $+75-1.1 \times 10^{6}$ & \\
\hline & & & & & & Day $+81-2.3 \times 10^{5}$ & \\
\hline & & & & CSF (2/2) & EBNA-1 & Day $+75-1.3 \times 10^{6}$ & CSF collected on Days $+\mathbf{7 5}$ and $+\mathbf{7 8}$ \\
\hline & & & & & & Day $+78-2.7 \times 10^{6}$ & \\
\hline & B. & $M / 42 y$ & PTLD & Whole Blood (1/5) & EBNA-1 & Day $+95-2.0 \times 10^{7}$ & $\begin{array}{l}\text { MUD HSCT for AML; Plasma EBV (qualitative) } \\
\text { PCR positive Day +96; Plasma collected on } \\
\text { Day }+\mathbf{9 5} \text { for EBV QPCR; Died on Day }+99 \\
\text { due to multi-organ failure }\end{array}$ \\
\hline & C. & F/59y & PTLD & Plasma (3/6) & EBNA-1 & Day $+45-2.2 \times 10^{5}$ & $\begin{array}{l}\text { MUD HSCT for AML; CMV reactivation on Day } \\
+44 \text {, Treatment with Foscarnet and } \\
\text { ganciclovir on Day +52; Plasma collected } \\
\text { Days }+38,+40,+\mathbf{4 5},+\mathbf{5 2} \text { and }+\mathbf{5 9} \text {; Died on } \\
\text { Day +66; EBV VCA IgG positive, HHV6 IgG } \\
\text { positive and CMV IgG positive pre-Tx }\end{array}$ \\
\hline & & & & & & Day $+52-9.6 \times 10^{3}$ & \\
\hline & & & & & & Day $+59-3.0 \times 10^{5}$ & \\
\hline & & & & Whole Blood (1/8) & EBNA-1 & Day $+46-6.6 \times 10^{4}$ & $\begin{array}{l}\text { EDTA collected Days }+3,+5,+10,+17,+26 \\
+31,+33,+46\end{array}$ \\
\hline & D. & M/48y & PTLD & Plasma $(4 / 6)$ & EBNA-1 & Day $+40-3.4 \times 10^{3}$ & $\begin{array}{l}\text { MUD HSCT for AML; EBV VCA IgG positive } \\
\text { pre-Tx; Plasma collected Days }+28,+33,+\mathbf{4 0}, \\
\mathbf{+ 4 7}, \mathbf{+ 5 4}, \mathbf{+ 6 1} \text {; Plasma EBV (qualitative) PCR } \\
\text { negative on Day }+62 \text {; Died Day }+\mathbf{7 2} \text { of multi- } \\
\text { organ failure }\end{array}$ \\
\hline & & & & & & Day $+47-3.6 \times 10^{4}$ & \\
\hline & & & & & & Day $+54-3.4 \times 10^{6}$ & \\
\hline & & & & & & Day $+61-6.3 \times 10^{6}$ & \\
\hline & & & & Whole Blood (2/2) & EBNA-1 & Day $+62-1.3 \times 10^{8}$ & EDTA collected Days $\boldsymbol{+ 6 2}$ and $\boldsymbol{+ 6 3}$ \\
\hline & & & & & & Day $+63-1.8 \times 10^{7}$ & \\
\hline & E. & F/57y & PTLD & Whole Blood (1/5) & EBNA-1 & $9.5 \times 10^{4}$ & $\begin{array}{l}\text { No serology results available however clinical } \\
\text { notes indicate EBV reactivation; Plasma EBV } \\
\text { (qualitative) PCR positive 9-16 days after VL } \\
\text { testing done; negative at 1-7 months } \\
\text { thereafter. }\end{array}$ \\
\hline \multirow[t]{14}{*}{2.} & F. & Unknown & $\mathrm{IM}$ & Plasma (1/1) & EBNA-1 & $3.7 \times 10^{4}$ & EBV VCA IgM positive \\
\hline & & & & & BHRF-1 & $1.6 \times 10^{4}$ & \\
\hline & G. & Unknown & IM & Plasma $(0 / 1)$ & EBNA-1 & 0 & EBV VCA IgM positive \\
\hline & & & & & BHRF-1 & 0 & \\
\hline & $\mathrm{H}$. & Unknown & $\mathrm{IM}$ & Plasma (1/1) & EBNA-1 & $7.6 \times 10^{3}$ & EBV VCA IgM positive \\
\hline & & & & & BHRF-1 & $1.5 \times 10^{3}$ & \\
\hline & I. & Unknown & IM & Plasma (1/1) & EBNA-1 & $2.3 \times 10^{3}$ & EBV VCA IgM positive \\
\hline & & & & & BHRF-1 & $8.7 \times 10^{4}$ & \\
\hline & J. & $M / 17 y$ & $\mathrm{IM}$ & Whole Blood (1/1) & EBNA-1 & $1.0 \times 10^{5}$ & EBV VCA IgM positive \\
\hline & & & & & BHRF-1 & $1.8 \times 10^{3}$ & \\
\hline & K. & $\mathrm{F} / 19 y$ & $\mathrm{IM}$ & Whole Blood (1/1) & EBNA-1 & $2.210^{3}$ & EBV VCA IgM positive \\
\hline & & & & & BHRF-1 & $5.6 \times 10^{4}$ & \\
\hline & $\mathrm{L}$. & $\mathrm{F} / 53 \mathrm{y}$ & $\mathrm{IM}$ & Whole Blood (1/1) & EBNA-1 & $2.0 \times 10^{5}$ & EBV VCA IgM positive; acute glandular fever \\
\hline & & & & & BHRF-1 & $1.8 \times 10^{4}$ & \\
\hline
\end{tabular}


Table 3: EBV DNA loads in various EBV-associated disease states and immunocompromised individuals (Continued)

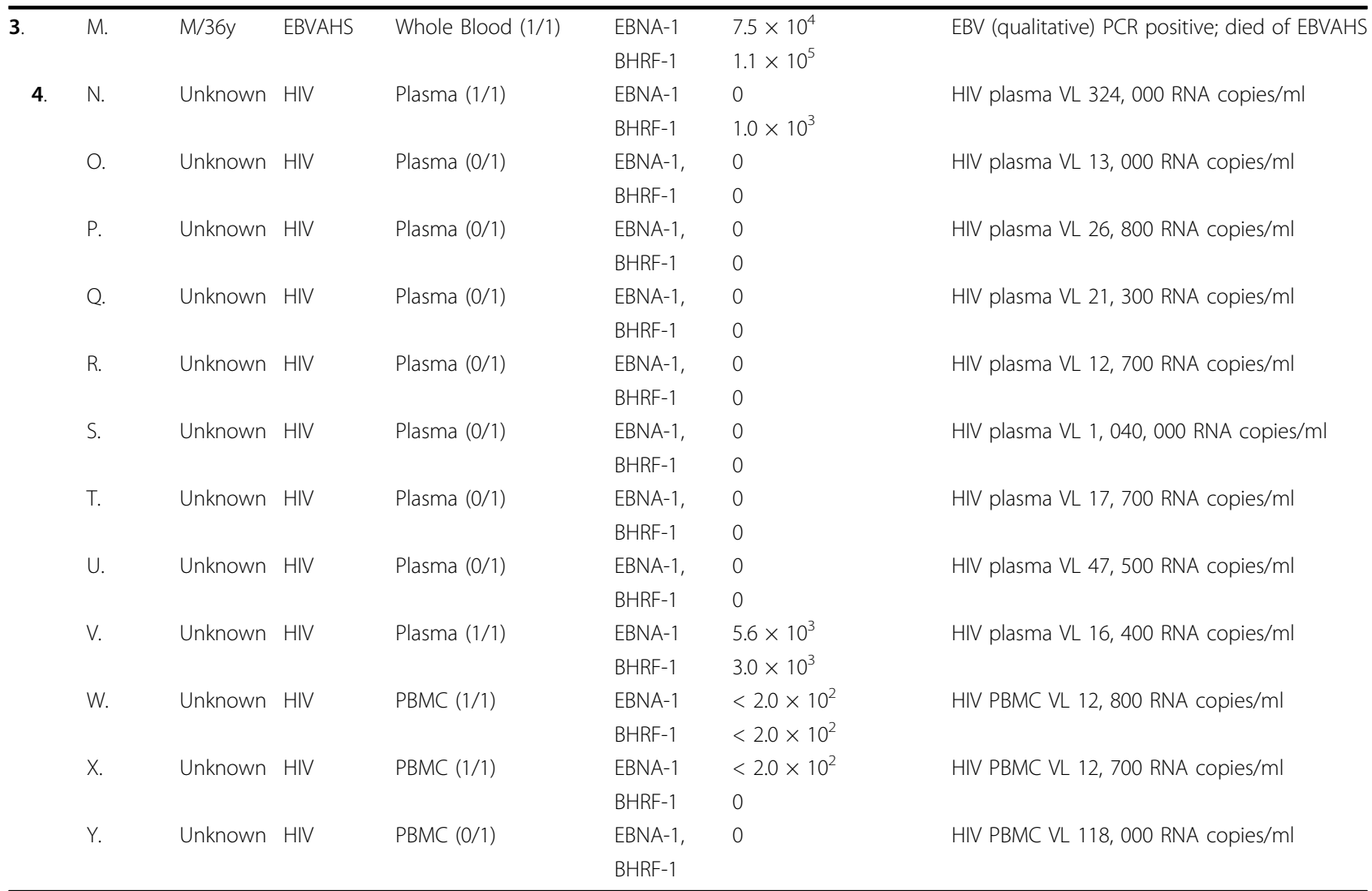

Abbreviations: Y, years; Group 1 (PTLD), post-transplant lymphoproliferative disease; Group 2 (IM), infectious mononucleosis; Group 3 (EBVAHS), Epstein-Barr virus associated-haemophagocytic syndrome; Group 4 (HIV infection), human immunodeficiency virus; EDTA, ethylenediaminetetraacetic acid; CSF, cerebrospinal fluid; PBMC, peripheral blood mononuclear cells; EBNA-1, Epstein-Barr virus nuclear antigen-1; BHRF-1, BamHI fragment $\mathrm{H}$ rightward open reading frame-1; ml, millilitres; Bold lettering indicates Day QPCR positive post-transplant; AML, acute myeloid leukaemia; MUD; matched unrelated donor; HSCT, haematopoietic stem cell transplantation; CMV, cytomegalovirus; VCA, viral capsid antigen; Ig, immunoglobulins; EA-D, early antigen-diffuse; EA-R, early antigen-restricted; VL, viral load.

on Day +62 whilst simultaneously QPCR positive in whole blood. EBV-specific serology results were available for four patients, and confirmed EBV infection prior to the transplant. Four patients died as a result of PTLD complications, on average +81.25 days post transplantation. In Group 2 (IM), EBV DNA was quantifiable from $1.5 \times 10^{3}$ to $2.0 \times 10^{5}$ copies $/ \mathrm{ml}$. One sample was negative for EBV DNA (Patient G), despite a positive EBV VCA IgM profile. Group 3 (EBVAHS) EBV DNA load results were similar to Group 2, however Patient $M$ died as a consequence of the disease condition. In Group 4 (HIV), EBV DNA was detectable in both plasma and PBMC ranging from $2.0 \times$ $10^{2}$ to $5.6 \times 10^{3}$ copies $/ \mathrm{ml}$. However, $50 \%$ of these samples were below $2.0 \times 10^{3}$ copies $/ \mathrm{ml}$.

\section{EBV detection and load in the population sample}

EBNA-1 and BHRF-1 DNA were detected in $11.0 \%$ and $21.6 \%$ of Group 5 (the population sample), respectively; $22.5 \%$ of samples were positive for at least one EBV DNA target (Table 4). Of the 24 EBNA-1 DNA positive samples, $91.7 \%$ were also BHRF-1 DNA positive, and of the 47 BHRF-1 DNA positive samples, $46.8 \%$ were also EBNA-1 DNA positive. Viral loads (combined targets) were detectable between $2.0 \times 10^{2}$ to $6.2 \times 10^{4}$ copies/ $\mathrm{ml}$ of whole blood, but $54.2 \%$ and $85.1 \%$ of samples were below $2.0 \times 10^{3}$ copies/ml for EBNA-1 and BHRF1 DNA levels, respectively. All samples with measurable EBV DNA were EBV VCA IgG antibody positive, which were found in $95.9 \%$ of the population sample. There was a modest correlation between VCA IgG antibody titres and BHRF-1 DNA load (Spearman's rho $=0.13$, $\mathrm{p}=0.05$ ) and a weaker (not statistically significant) correlation between EBNA-1 DNA load and VCA IgG antibody titres (Spearman's rho $=0.11, \mathrm{p}=0.11$ ) $($ Table 4$)$.

\section{Discussion}

With increasing availability of nucleic acid testing (NAT) methods, measuring EBV DNA in blood has proven valuable in diagnosing and monitoring PTLD [16,21,22,37-41], NPC [42,43], IM [13,44], EBV infection in $\mathrm{HIV}$-infected individuals $[8,13,45], \mathrm{BL}$ [13] and chronic active EBV infection $[18,46]$. In this study, we 
Table 4 EBV DNA load and antibody titre detection rates in the population samples (Group 5, $\mathbf{n}=\mathbf{2 1 8}$ )

\begin{tabular}{|c|c|c|c|c|c|c|}
\hline \multirow[t]{2}{*}{ Target } & \multirow{2}{*}{$\begin{array}{c}\text { Positive } \\
\text { n (\%) }\end{array}$} & \multirow[t]{2}{*}{ Detectable Range } & \multicolumn{4}{|c|}{ Spearman correlation $(p)$} \\
\hline & & & $\begin{array}{l}\text { EBNA-1 DNA } \\
\text { load }\end{array}$ & $\begin{array}{l}\text { BHRF-1 DNA } \\
\text { load }\end{array}$ & $\begin{array}{l}\text { Combined EBV Targets } \\
\text { DNA load }\end{array}$ & $\begin{array}{l}\text { VCA } \\
\text { lgG }\end{array}$ \\
\hline $\begin{array}{l}\text { EBV EBNA-1 DNA load } \\
\text { (copies/ml) }\end{array}$ & $24(11.0 \%)$ & $2.0 \times 10^{2}-9.1 \times 10^{4}$ & 1.00 & & & \\
\hline $\begin{array}{l}\text { EBV BHRF-1 DNA load } \\
\text { (copies } / \mathrm{ml})\end{array}$ & $47(21.6 \%)$ & $2.0 \times 10^{2}-3.3 \times 10^{4}$ & $\begin{array}{l}0.63 \\
p<0.001\end{array}$ & 1.00 & & \\
\hline $\begin{array}{l}\text { Combined EBV targets DNA } \\
\text { load } \\
\text { (mean of BHRF \& EBNA loads } \\
\text { where both } \\
\text { positive) (copies } / \mathrm{ml} \text { ) }\end{array}$ & $49(22.5 \%)$ & $2.0 \times 10^{2}-6.2 \times 10^{4}$ & $\begin{array}{l}0.73 \\
p<0.001\end{array}$ & $\begin{array}{l}0.97 \\
p<0.001\end{array}$ & 1.00 & \\
\hline $\begin{array}{l}\text { Viral capsid antigen lgG } \\
\text { (titres) }\end{array}$ & $209(95.9 \%)$ & $1: 10-1: 5120$ & $\begin{array}{l}0.11 \\
p=0.11\end{array}$ & $\begin{array}{l}0.13 \\
p=0.05\end{array}$ & $\begin{array}{l}0.14 \\
p=0.04\end{array}$ & 1.00 \\
\hline
\end{tabular}

Abbreviations: EBV, Epstein-barr virus; EBNA-1, Epstein-barr virus nuclear antigen-1; BHRF-1, BamHI fragment $\mathrm{H}$ rightward open reading frame-1; VCA, viral capsid antigen; IgG, immunoglobulin G; Pos, positive.

successfully developed two in-house QPCR methods incorporating a novel single quantification standard containing two EBV DNA targets for measuring viral load on the Rotor-Gene $6000^{\mathrm{m}}$. Substituting SYBR Green I dye as a fluorescent marker for product accumulation over fluorogenic probes, this method proved useful for quantifying EBV DNA concentrations in clinical samples from individuals with a variety of EBV-associated disorders or immune dysfunctions and in a healthy population sample.

Previous studies in PTLD have found that EBV DNA loads increased with disease progression and decreased with remission of lymphoproliferation $[47,48]$. This pattern was observed in Group 1, where EBV DNA loads appeared to be correlated with disease status. We found similar EBV DNA loads to those previously reported, with most studies showing EBV DNA concentrations ranging from $5.0 \times 10^{2}$ to $2.0 \times 10^{7}$ copies $/ \mathrm{ml}$ in whole blood, plasma and serum $[37,49,50]$. EBV DNA was also detected in CSF at concentrations comparable to plasma, however detectable CSF EBV DNA has been previously reported only in association with acquired immunodeficiency syndrome (AIDS)-related brain lymphoma [51]. The significance of EBV DNA in CSF of PTLD remains to be elucidated.

EBV DNA loads in IM patients were also similar to those reported in the literature [13,22,26,44,52], although some authors described loads as high as $10^{6}$ and $10^{7}$ copies/ml $[12,46,53]$. In Group 3, EBV DNA loads were consistent with acute phase EBVAHS [46,54], and correlated with the deterioration of the patient's disease condition. Elazary et al also found that a viral load ranging from $10^{4}-10^{5}$ copies $/ \mathrm{ml}$ was associated with poor patient outcome [54]. One study found much higher EBV DNA loads (up to $10^{7}$ copies/ml) [55], but this may have been due to differences in sample type and detection methods. In Group 4, EBV DNA was detected in 33\% of samples
(22\% of plasma, $67 \%$ of PBMC), compared to $34 \%$ to $76 \%$ positivity reported in other studies $[8,26]$. Notably however, these studies used whole blood for quantifying EBV DNA load, which could have increased the probability of viral DNA detection. As none of the Group 4 patients were known to have EBV-related disease, low positivity ratios and viral loads were expected.

Similar to our findings, the literature describes EBV DNA detectable from $10^{2}$ to $10^{4}$ copies $/ \mathrm{ml}$ and positivity ratios up to $29 \%$ in whole blood of healthy individuals [11-13,26,38,56-59]. However, DNA loads as high as $5.5 \times 10^{5}$ copies $/ \mathrm{ml}$ of whole blood and a positivity ratio of $72 \%$ have been reported [58]. Differences in the results may be attributable to more sensitive methods associated with nested PCR and dual-labelled probes [58]. Interestingly, another study showed 100\% EBV DNA positivity in whole blood, although DNA loads were all below the detection limit of the assay $\left(2.0 \times 10^{3}\right.$ copies $\left./ \mathrm{ml}\right)$ [38].

In the population sample the EBV VCA IgG antibody detection rate was consistent with levels of EBV sero-positivity in Western societies [2]. One study previously showed a correlation between EBV VCA IgG antibody titres and EBV viral load (detectable versus non-detectable) [60]. We similarly found a modest correlation with quantitative BHRF-1 DNA loads, and a weaker (not statistically significant) correlation with EBNA-1 DNA load (see Table 4).

We noted some discrepancies in our measures of EBV positivity. In one PTLD patient (Patient D), plasma was qualitative EBV PCR negative whilst simultaneously reporting an EBV DNA load of $1.3 \times 10^{8}$ copies $/ \mathrm{ml}$ in whole blood. However, a growing number of studies have shown that cell-associated EBV is detectable before plasma EBV DNA and can persist without accompanying plasma DNA loads [21,48]. In Group 2, Patient G, despite being EBV VCA IgM antibody positive, was EBV QPCR negative. As EBV DNA loads can change rapidly 
from being undetectable to being very high in a short period of time [38], it is possible that sampling occurred late in the convalescent phase where low EBV DNA positivity ratios of $44 \%$ have been previously reported [46]. Other factors contributing to DNA load variation include differences in sample type, method of extraction or NAT, and target chosen for PCR amplification.

As specimen type is known to influence DNA loads and impact on assay performance [36], unfractionated EDTA whole blood was used for DNA quantification where possible. The dynamic changes of EBV DNA are better reflected in circulating whole blood [38], which also contains all the compartments that may harbour virus $[13,21,61]$. However, despite reports of greater test sensitivity with whole blood [12,36], EBV DNA load has also been quantified in PBMC [14,16,62-64]. Although infection is typically associated with cell compartments $[8,12,13]$, EBV DNA is also found in cell-free blood partitions such as plasma or serum, usually in fragmented, cellderived form [12]. In this study, 2 of 9 plasma samples from HIV-infected patients had detectable EBV DNA, compared to 2 out of 3 PBMC samples. As we did not have simultaneous plasma and PBMC samples from the same individuals, we were unable to assess the differences in viral load between these compartments. Further studies comparing suitability of different sample types in various EBV-related diseases and immune disorders are required.

The method of DNA purification is known to affect viral load measurements. One study showed yield from manually extracted DNA was $57 \%$ higher than that of robotic systems [65]. Therefore, to improve DNA recovery and maximise PCR sensitivity, samples here were purified using a commercial silica-based column method $[61,66]$. For optimal quantitation results, an earlier study showed that DNA should be subjected to PCR within one to two weeks post-extraction [67]. Here, delay between extraction and testing could have contributed to low DNA loads and positivity ratios in clinical samples. Furthermore, DNA from blood samples that had undergone more than four freeze-thaw cycles were found to be partially degraded [68]. Since the clinical samples used here were tested retrospectively, monitoring these conditions were not possible.

EBV DNA loads also vary according to type and size of gene target [69]. Ryan et al, found assay sensitivity was dependent on the specific gene segment and that different targets had varying lower limits of detection [15]. For EBV, BamHI-W is reportedly 10 times more sensitive than other targets for PCR, allowing for detection of viral DNA at trace amounts $[8,13,15]$. However, precise quantification of viral genomes is complicated by the number of reiterated BamHI-W sequences among EBV strains, which typically ranges between 7 and 11 repeats per genome [15]. To avoid overestimation in this study, we chose to use the next most sensitive EBV gene; EBNA-1 [15], and an abundantly expressed gene, BHRF-1, for QPCR.

Despite targeting highly conserved EBV regions, selective drop out of amplifiable EBV DNA at the EBNA-1 and BHRF-1 loci was observed in Group 4 (Patients $\mathrm{N}$ and $\mathrm{X})$, and in 25 of 218 (11.5\%) whole bloods from the population sample. Instead of amplifying both EBV DNA genes, only one target was detected, 93\% of which had viral loads less than $2.0 \times 10^{3}$ copies $/ \mathrm{ml}$. As betaglobin was detected in all samples, PCR inhibitors and/ or defective nucleic acid purification methods were excluded [70]. Alternatively, selective drop out may have been due to low viral load and/or sampling error [71]. Since load determination is reliant on the amount of EBV genomes pipetted into a reaction and assumes viral homogeneity, QPCR results, particularly at low viral load levels are prone to random sampling error. This phenomenon is well documented in DNA quantification and results in less reliable viral load measurements [70,71]. Therefore, samples reporting low levels of target nucleic acid may not be reproducible in repeated assays from the same or different specimens [72].

Currently, there are no standardised methods for measuring EBV DNA, complicating inter-laboratory comparisons in multicentre studies of EBV-related diseases. Standardisation is difficult as PCR assay conditions vary between laboratories, leading to variations in the accuracy and reproducibility of viral load quantification [21]. Although there appears to be a strong concordance between laboratories for qualitative EBV DNA estimates, there continues to be marked inconsistency in quantitative results [73]. It has been suggested that the use of unfractionated whole blood [26] or an international calibration standard could be the first step towards standardisation [73]. However, instrumentation, chemistries, gene targets and other test-related aspects remain diverse. One solution for enabling inter-laboratory comparisons is the distribution of proficiency panels such as QCMD. Such programs have already been used for assessing methods for the detection and quantification of EBV and other viruses [27,74,75].

\section{Conclusion}

This is the first reported study that uses the SYBR Green I dye on the Rotor-gene $6000^{\text {TM }}$ with a novel quantification standard containing two EBV targets for measuring EBV DNA load. The assays proved successful in the quantification of EBV genomes in clinical cases and should be considered as a cost effective and sensitive PCR alternative to probe-based assays. This approach can be modified to detect and quantify other latent 
herpesviruses such as HHV6, CMV, and VZV. This procedure is suitable for robotics and automation, and would be a useful addition in larger laboratories.

\section{Acknowledgements}

The Ausimmune Investigator Group includes C Chapman, A Coulthard, K Dear, T Dwyer, T Kilpatrick, R Lucas, T McMichael, MP Pender, A-L Ponsonby, B Taylor, P Valery, I van der Mei and D Williams. The Ausimmune Study is funded by the National Multiple Sclerosis Society of the USA, the National Health \& Medical Research Council (Project Grant 316901) and Multiple Sclerosis Research Australia. We also acknowledge the work of the Ausimmune Study research nurses who undertook sample collection: $S$ Agland, B Alexander, M Davis, Z Dunlop, A Wright, R Scott, J Selvidge, M Steele, K Turner, B Wood and the study project officers, H Rodgers and C Jozwick. Clinical samples were kindly provided by N Gilroy, D Gottlieb, P Ferguson, F Kwok and I Kay. We would also like to thank B Wang of the Westmead Millennium Institute for assisting with the cloning work, B OToole for statistical analyses, D Patel for assistance with the serology and C Toi for laboratory guidance and review of the manuscript.

\section{Author details}

${ }^{1}$ Virology Department, Centre For Infectious Diseases \& Microbiology Laboratory Services, Institute of Clinical Pathology \& Medical Research, Institute Road, Westmead Hospital, Westmead 2145, New South Wales, Australia. ${ }^{2}$ National Centre for Epidemiology and Population Health, The Australian National University, Canberra, ACT, 0200 Australia. ${ }^{3}$ Murdoch Childrens Research Institute, 9th Floor AP Building, The Royal Children's Hospital, Flemington Road, Parkville, Victoria 3052, Australia.

\section{Authors' contributions}

MLL developed the assays, carried out all of the DNA work, assisted in the data analysis and result interpretation, and writing of the manuscript. On behalf of the Ausimmune Investigator group, RML supplied the whole blood and serum from the population sample, and was involved in the data analysis. VMR aided in primer design and JT performed the serology testing. $M L L, D E D, V M R, R M L$ and ALP were involved in the design and conception of the study. All authors have read, reviewed and approved the final manuscript.

\section{Competing interests}

The authors declare that they have no competing interests.

Received: 26 May 2010 Accepted: 22 September 2010 Published: 22 September 2010

\section{References}

1. Steven NM: Epstein-Barr virus latent infection in vivo. Rev Med Virol 1997, 7(2):97-106.

2. Hess RD: Routine Epstein-Barr virus diagnostics from the laboratory perspective: still challenging after 35 years. J Clin Microbiol 2004, 42(8):3381-7.

3. Tsai $D E$, et al: $E B V P C R$ in the diagnosis and monitoring of posttransplant lymphoproliferative disorder: results of a two-arm prospective trial. Am J Transplant 2008, 8(5):1016-24

4. Loginov $\mathrm{R}$, et al: Monitoring of EBV-DNAemia by quantitative real-time PCR after adult liver transplantation. J Clin Virol 2006, 37(2):104-108.

5. Timbury MC, Edmond E: Herpesviruses. J Clin Pathol 1979, 32(9):859-81.

6. Cohen Jl: Epstein-Barr virus infection. N Engl J Med 2000, 343(7):481-92.

7. Kimura $\mathrm{H}$, et al: Viral load in Epstein-Barr virus-associated hemophagocytic syndrome. Microbiol Immunol 2002, 46(8):579-82.

8. Stevens SJ, et al: High Epstein-Barr virus (EBV) DNA loads in HIV-infected patients: correlation with antiretroviral therapy and quantitative EBV serology. AIDS 2002, 16(7):993-1001

9. Espy MJ, et al: Comparison of three methods for extraction of viral nucleic acids from blood cultures. J Clin Microbiol 1995, 33(1):41-4.

10. Leung $E$, et al: Dynamic EBV gene loads in renal, hepatic, and cardiothoracic transplant recipients as determined by real-time PCR light cycler. Transpl Infect Dis 2004, 6(4):156-64.
11. Bai $X$, et al: Quantitative polymerase chain reaction for human herpesvirus diagnosis and measurement of Epstein-Barr virus burden in posttransplant lymphoproliferative disorder. Clin Chem 1997, 43(10):1843-9.

12. Kozic $S$, et al: Evaluation of a commercial real-time PCR assay for quantitation of Epstein-Barr virus DNA in different groups of patients. J Virol Methods 2006, 135(2):263-8, Epub 2006 May 2

13. Stevens SJ, Pronk I, Middeldorp JM: Toward standardization of EpsteinBarr virus DNA load monitoring: unfractionated whole blood as preferred clinical specimen. J Clin Microbiol 2001, 39(4):1211-6.

14. Leung $E$, et al: Use of real-time PCR to measure Epstein-Barr virus genomes in whole blood. J Immunol Methods 2002, 270(2):259-67.

15. Ryan $J$, et al: Epstein-Barr virus quantitation by real-time PCR targeting multiple gene segments: a novel approach to screen for the virus in paraffin-embedded tissue and plasma. J Mol Diagn 2004, 6(4):378-85.

16. Rowe DT, et al: Use of quantitative competitive PCR to measure EpsteinBarr virus genome load in the peripheral blood of pediatric transplant patients with lymphoproliferative disorders. J Clin Microbiol 1997, 35(6):1612-5.

17. Fan $H$, Gulley ML: Epstein-Barr viral load measurement as a marker of EBV-related disease. Mol Diagn 2001, 6(4):279-89.

18. Kimura $\mathrm{H}$, et al: Quantitative analysis of Epstein-Barr virus load by using a real-time PCR assay. J Clin Microbiol 1999, 37(1):132-6.

19. Lo YM, et al: Quantitative and temporal correlation between circulating cell-free Epstein-Barr virus DNA and tumor recurrence in nasopharyngeal carcinoma. Cancer Res 1999, 59(21):5452-5.

20. Lo YM, et al: Quantitative analysis of cell-free Epstein-Barr virus DNA in plasma of patients with nasopharyngeal carcinoma. Cancer Res 1999, 59(6):1188-91.

21. Stevens SJ, et al: Role of Epstein-Barr virus DNA load monitoring in prevention and early detection of post-transplant lymphoproliferative disease. Leuk Lymphoma 2002, 43(4):831-40.

22. Niesters HGM, et al: Development of a real-time quantitative assay for detection of Epstein-Barr virus. J Clin Microbiol 2000, 38(2):712-5.

23. Xu S, et al: A comparison of quantitative-competitive and realtime PCR assays using an identical target sequence to detect Epstein-Barr virus viral load in the peripheral blood. J Virol Methods 2006, 137(2):205-12.

24. Brengel-Pesce $K$, et al: Routine use of real-time quantitative PCR for laboratory diagnosis of Epstein-Barr virus infections. J Med Virol 2002, 66(3):360-9.

25. Mackay IM, Arden KE, Nitsche A: Real-time PCR in virology. Nucleic Acids Res 2002, 30(6):1292-305.

26. Fafi-Kremer $\mathrm{S}$, et al: Evaluation of the Epstein-Barr virus R-gene quantification kit in whole blood with different extraction methods and PCR platforms. J Mol Diagn 2008, 10(1):78-84

27. Ruiz $G$, et al: Comparison of commercial real-time PCR assays for quantification of Epstein-Barr virus DNA. J Clin Microbiol 2005, 43(5):2053-7.

28. Papin JF, Vahrson W, Dittmer DP: SYBR green-based real-time quantitative PCR assay for detection of West Nile Virus circumvents false-negative results due to strain variability. J Clin Microbiol 2004, 42(4):1511-8.

29. Karlsen F, Steen HB, Nesland JM: SYBR green I DNA staining increases the detection sensitivity of viruses by polymerase chain reaction. $J$ Virol Methods 1995, 55(1):153-6.

30. Hilscher C, Vahrson W, Dittmer DP: Faster quantitative real-time PCR protocols may lose sensitivity and show increased variability. Nucleic Acids Res 2005, 33(21):e182.

31. Lucas RM, et al: Associations between silicone skin cast score, cumulative sun exposure, and other factors in the ausimmune study: a multicenter Australian study. Cancer Epidemiol Biomarkers Prev 2009, 18(11):2887-94.

32. Humme $S$, et al: The EBV nuclear antigen 1 (EBNA1) enhances B cell immortalization several thousandfold. Proc Natl Acad Sci USA 2003, 100(19):10989-94.

33. Lee MA, Diamond ME, Yates JL: Genetic evidence that EBNA-1 is needed for efficient, stable latent infection by Epstein-Barr virus. J Virol 1999, 73(4):2974-82

34. Henderson $S$, et al: Epstein-Barr virus-coded BHRF1 protein, a viral homologue of Bcl-2, protects human B cells from programmed cell death. Proc Natl Acad Sci USA 1993, 90(18):8479-83. 
35. Huang $Y$, et al: Proper developmental control of human globin genes reproduced by transgenic mice containing a 160-kb BAC carrying the human beta-globin locus. Blood Cells Mol Dis 2000, 26(6):598-610.

36. Hakim $\mathrm{H}$, et al: Comparison of various blood compartments and reporting units for the detection and quantification of Epstein-Barr virus in peripheral blood. J Clin Microbiol 2007, 45(7):2151-5

37. van Esser JW, et al: Molecular quantification of viral load in plasma allows for fast and accurate prediction of response to therapy of Epstein-Barr virus-associated lymphoproliferative disease after allogeneic stem cell transplantation. Br J Haematol 2001, 113(3):814-21.

38. Stevens SJ, et al: Frequent monitoring of Epstein-Barr virus DNA load in unfractionated whole blood is essential for early detection of posttransplant lymphoproliferative disease in high-risk patients. Blood 2001, 97(5):1165-71.

39. Lucas KG, et al: Semiquantitative Epstein-Barr virus (EBV) polymerase chain reaction for the determination of patients at risk for EBV-induced lymphoproliferative disease after stem cell transplantation. Blood 1998, 91(10):3654-61.

40. Kimura $\mathrm{H}$, et al: Measuring Epstein-Barr virus (EBV) load: the significance and application for each EBV-associated disease. Rev Med Virol 2008 18(5):305-19.

41. Wheless SA, et al: Post-transplantation lymphoproliferative disease: Epstein-Barr virus DNA levels, HLA-A3, and survival. Am J Respir Crit Care Med 2008, 178(10):1060-5.

42. Chan KC, et al: Molecular characterization of circulating EBV DNA in the plasma of nasopharyngeal carcinoma and lymphoma patients. Cancer Res 2003, 63(9):2028-32.

43. Lin JC, et al: Quantification of plasma Epstein-Barr virus DNA in patients with advanced nasopharyngeal carcinoma. N Engl J Med 2004, 350(24):2461-70.

44. Bauer CC, et al: Serum Epstein-Barr virus DNA load in primary EpsteinBarr virus infection. J Med Virol 2005, 75(1):54-8.

45. Dehee $A$, et al: Quantification of Epstein-Barr virus load in peripheral blood of human immunodeficiency virus-infected patients using realtime PCR. J Med Virol 2001, 65(3):543-52.

46. Yamamoto $M$, et al: Detection and quantification of virus DNA in plasma of patients with Epstein-Barr virus-associated diseases. J Clin Microbiol 1995, 33(7):1765-8

47. Wagner $\mathrm{HJ}$, et al: Patients at risk for development of posttransplant lymphoproliferative disorder: plasma versus peripheral blood mononuclear cells as material for quantification of Epstein-Barr viral load by using real-time quantitative polymerase chain reaction. Transplantation 2001, 72(6):1012-9.

48. Rowe DT, et al: Epstein-Barr virus load monitoring: its role in the prevention and management of post-transplant lymphoproliferative disease. Transpl Infect Dis 2001, 3(2):79-87.

49. Rosselet $A$, et al: Associations of serum EBV DNA and gammopathy with post-transplant lymphoproliferative disease. Clin Transplant 2009, 23(1):74-82.

50. Wada K, et al: Simultaneous quantification of Epstein-Barr virus, cytomegalovirus, and human herpesvirus 6 DNA in samples from transplant recipients by multiplex real-time PCR assay. J Clin Microbiol 2007, 45(5):1426-32.

51. Bossolasco S, et al: Epstein-Barr virus DNA load in cerebrospinal fluid and plasma of patients with AIDS-related lymphoma. J Neurovirol 2002, 8(5):432-8.

52. Stevens SJ, et al: Monitoring of epstein-barr virus DNA load in peripheral blood by quantitative competitive PCR. J Clin Microbiol 1999, 37(9):2852-7.

53. van Laar JA, et al: Epstein-Barr viral load assessment in immunocompetent patients with fulminant infectious mononucleosis. Arch Intern Med 2002, 162(7):837-9.

54. Elazary AS, et al: Severe Epstein-Barr virus-associated hemophagocytic syndrome in six adult patients. J Clin Virol 2007, 40(2):156-9.

55. Teramura T, et al: Quantitative analysis of cell-free Epstein-Barr virus genome copy number in patients with EBV-associated hemophagocytic lymphohistiocytosis. Leuk Lymphoma 2002, 43(1):173-9.

56. Compston LI, et al: Multiplex real-time PCR for the detection and quantification of latent and persistent viral genomes in cellular or plasma blood fractions. J Virol Methods 2008, 151(1):47-54
57. Kullberg-Lindh C, et al: Comparison of serum and whole blood levels of cytomegalovirus and Epstein-Barr virus DNA. Transpl Infect Dis 2008, 10(5):308-15.

58. Hudnall SD, et al: Herpesvirus prevalence and viral load in healthy blood donors by quantitative real-time polymerase chain reaction. Transfusion 2008, 48(6):1180-7

59. Engelmann I, et al: Rapid quantitative PCR assays for the simultaneous detection of herpes simplex virus, varicella zoster virus, cytomegalovirus, Epstein-Barr virus, and human herpesvirus 6 DNA in blood and other clinical specimens. J Med Virol 2008, 80(3):467-77.

60. Besson C, et al: Positive correlation between Epstein-Barr virus viral load and anti-viral capsid immunoglobulin $\mathrm{G}$ titers determined for Hodgkin's lymphoma patients and their relatives. J Clin Microbiol 2006, 44(1):47-50.

61. Fafi-Kremer $\mathrm{S}$, et al: Assessment of automated DNA extraction coupled with real-time PCR for measuring Epstein-Barr virus load in whole blood, peripheral mononuclear cells and plasma. J Clin Virol 2004, 30(2):157-64

62. Jabs WJ, et al: Normalized quantification by real-time PCR of Epstein-Barr virus load in patients at risk for posttransplant lymphoproliferative disorders. J Clin Microbiol 2001, 39(2):564-9.

63. Wadowsky RM, et al: Measurement of Epstein-Barr virus DNA loads in whole blood and plasma by TaqMan PCR and in peripheral blood lymphocytes by competitive PCR. J Clin Microbiol 2003, 41(11):5245-9.

64. Baldanti $F$, et al: Kinetics of Epstein-Barr virus DNA load in different blood compartments of pediatric recipients of T-cell-depleted HLAhaploidentical stem cell transplantation. J Clin Microbiol 2008, 46(11):3672-7.

65. Riemann $\mathrm{K}$, et al: Comparison of manual and automated nucleic acid extraction from whole-blood samples. J Clin Lab Anal 2007, 21(4):244-8.

66. Schuurman T, et al: Reduced PCR sensitivity due to impaired DNA recovery with the MagNA Pure LC total nucleic acid isolation kit. J Clin Microbiol 2005, 43(9):4616-22.

67. Malcomson RD, et al: The scope of quantitative polymerase chain reaction assays in clinical molecular pathology. Clin Mol Pathol 1995, 48(4):M178-M183.

68. Lahiri DK, Schnabel B: DNA isolation by a rapid method from human blood samples: effects of $\mathrm{MgCl} 2$, EDTA, storage time, and temperature on DNA yield and quality. Biochem Genet 1993, 31(7-8):321-8.

69. Stevens SJ, et al: Diagnostic value of measuring Epstein-Barr virus (EBV) DNA load and carcinoma-specific viral mRNA in relation to anti-EBV immunoglobulin A $(\lg A)$ and $\lg G$ antibody levels in blood of nasopharyngeal carcinoma patients from Indonesia. J Clin Microbiol 2005, 43(7):3066-73.

70. Gulley ML, Fan H, Elmore SH: Validation of Roche LightCycler Epstein-Barr virus quantification reagents in a clinical laboratory setting. $J$ Mol Diagn 2006, 8(5):589-97.

71. Diaco D: Practical Considerations for the Design of Quantitative PCR Assays. In PCR Strategies. Edited by: G DH, S JJ, Innis MA. Academic Press Limited, London; 1995:84-107.

72. Smith TF, et al: Quantitative real-time polymerase chain reaction for evaluating DNAemia due to cytomegalovirus, Epstein-Barr virus, and BK virus in solid-organ transplant recipients. Clin Infect Dis 2007, 45(8):1056-61.

73. Hayden RT, et al: Multicenter comparison of different real-time PCR assays for quantitative detection of Epstein-Barr virus. J Clin Microbiol 2008, 46(1):157-63.

74. Perandin F, et al: Comparison of commercial and in-house Real-time PCR assays for quantification of Epstein-Barr virus (EBV) DNA in plasma. BMC Microbiol 2007, 7:22.

75. Pillet $\mathrm{S}$, Bourlet $\mathrm{T}$, Pozzetto B: Comparative evaluation of a commercially available automated system for extraction of viral DNA from whole blood: application to monitoring of epstein-barr virus and cytomegalovirus load. J Clin Microbiol 2009, 47(11):3753-5.

doi:10.1186/1743-422X-7-252

Cite this article as: Lay et al:: Measurement of Epstein-Barr virus DNA load using a novel quantification standard containing two EBV DNA targets and SYBR Green I dye. Virology Journal 2010 7:252. 